\title{
Regulating the disposal of cigarette butts as toxic hazardous waste
}

\author{
Richard L Barnes
}

Center for Tobacco Control Research and Education, University of California, San Francisco, Dan Francisco, California, USA

\section{Correspondence to} Richard L Barnes, Center for Tobacco Control Research and Education, University of California, San Francisco, 530 Parnassus Ave, Suite 366 San Francisco, CA 94143-1390: USA; richard.barnes@ucsf.edu

Received 12 November 2010 Accepted 23 February 2011

\section{(2) UNLOCKAD}

This paper is freely available online under the BMJ Journals unlocked scheme, see http:// tobaccocontrol.bmj.com/site/ about/unlocked.xhtml

\section{ABSTRACT}

The trillions of cigarette butts generated each year throughout the world pose a significant challenge for disposal regulations, primarily because there are millions of points of disposal, along with the necessity to segregate, collect and dispose of the butts in a safe manner, and cigarette butts are toxic, hazardous waste. There are some hazardous waste laws, such as those covering used tyres and automobile batteries, in which the retailer is responsible for the proper disposal of the waste, but most post-consumer waste disposal is the responsibility of the consumer. Concepts such as extended producer responsibility (EPR) are being used for some post-consumer waste to pass the responsibility and cost for recycling or disposal to the manufacturer of the product. In total, 32 states in the US have passed EPR laws covering auto switches, batteries, carpet, cell phones, electronics, fluorescent lighting, mercury thermostats, paint and pesticide containers, and these could be models for cigarette waste legislation. A broader concept of producer stewardship includes EPR, but adds the consumer and the retailer into the regulation. The State of Maine considered a comprehensive product stewardship law in 2010 that is a much better model than EPR. By using either EPR or the Maine model, the tobacco industry will be required to cover the cost of collecting and disposing of cigarette butt waste. Additional requirements included in the Maine model are needed for consumers and businesses to complete the network that will be necessary to maximise the segregation and collection of cigarette butts to protect the environment.

\section{WHAT MAKES CIGARETTE BUTT WASTE POLLUTION A DIFFICULT WASTE DISPOSAL PROBLEM?}

To begin to grapple with this issue, one must appreciate the sheer magnitude of the problem. More than 5 trillion cigarettes are smoked worldwide each year, and all of them are disposed of in some manner. ${ }^{1}$ There are literally millions of points of deposit on the planet. They are dropped on the ground, tossed in trash bins and carted off to landfills with little or no thought being given by the smoker or society at large as to what that means to the environment. Regardless of how the butts are disposed of today, each one of them may pose a toxic hazard to the environment.

Cigarette butts comprise an estimated $30 \%$ of the total litter (by count) along US shorelines, waterways and on land, ${ }^{2}$ and Keep America Beautiful reported that $80 \%$ of all marine debris originates from land-based sources. ${ }^{3}$ Typically, discarded cigarette butts consist of three components: unsmoked remnant tobacco (including partially smoked/charred tobacco on the end), the filter of a filtered cigarette and a paper wrap. Each of these components of the discarded cigarette butt presents its own concerns. About $99 \%$ of the manufactured cigarette market is filtered cigarettes; filters degrade very slowly and thus become an accumulating mass of potentially toxic waste. Toxic substances are leached from the filter and tobacco residue ${ }^{4}$ that pollute waterways, ${ }^{5}$ and probably pollute ground water near landfills that are not properly constructed to contain such leachates. Aquatic life may be harmed by the toxic leachates, ${ }^{1}{ }^{6}$ and the butts may cause physical harm when ingested by animals. ${ }^{1}{ }^{7}$ Butts collect in municipal storm drains and then may empty into waterways, ${ }^{1}$ and can clog storm drains and sanitary sewer systems. ${ }^{8}$

Some attempts have been made to change smoker's behaviour towards cigarette butt deposition by enforcing existing anti-littering laws. In addition, some communities have imposed cigarette butt abatement fees on each pack of cigarettes. ${ }^{1}$ In San Francisco in 2009, a US\$0.20 fee was added to the price of cigarettes sold in the city, ${ }^{9}$ providing an economic disincentive towards tobacco product purchases. However, this fee is in abeyance pending litigation ${ }^{10}$ brought by the tobacco industry. If implemented, the fee would also support a public education campaign directed towards reducing butt waste, as well as recouping the costs to the city of butt clean-up. ${ }^{19}{ }^{10}$ Antilittering laws are not vigorously enforced regarding cigarette butt waste in most jurisdictions, but these may reduce the number of cigarette butts dropped on the ground. Nevertheless, these regulatory efforts are miniscule when compared with the scope of the problem.

Unlike a number of consumer products, there is no known value in recycling cigarette butts, though a number of new proprietary efforts have been publicised. ${ }^{11-13}$ Destruction of the butts through combustion $^{14}$ is a possibility, if the airborne components of combustion are not hazardous and the combustion residue could be disposed of safely. There is also the issue of who pays for the disposal. Incineration does not recover anything of value, where boiler and industrial furnace disposal does create energy and may recover some material. Tobacco contains trace amount of several heavy metals, but it is unlikely that any material recovery would be economically viable. Assuming that any of these reuse and disposal methods are efficacious, there is no known current process for segregating and collecting butts for reuse or disposal anywhere in the world. 


\section{HAZARDOUS WASTE DISPOSAL MODELS}

One must consider how other post-consumer hazardous waste is segregated and collected may serve as a model for cigarette butt waste. Tyres and lead-acid batteries are two examples of post-consumer waste collection that generally have been acceptable to consumers. When new tyres ${ }^{15}$ or a new automobile battery ${ }^{16}$ are purchased, the retailer takes responsibility for disposing of the used product under US government guidelines and state laws. Most other post-consumer hazardous waste disposal regulation relies on the consumer to dispose of it safely and properly, and many states have laws regulating the disposal of some of these products, such as flashlight batteries, compact fluorescent light (CFL) fixtures and paint. ${ }^{17} 18$ We know that tobacco contains thousands of different and potentially hazardous compounds ${ }^{119}$ and that cigarette butts in water leach a variety of toxic wastes, including heavy metals, nicotine and ethyl phenol. ${ }^{6}$

However, we have very limited knowledge on the actual toxic impact of these compounds in the environment. ${ }^{20}$ By applying the precautionary principle to the issue of cigarette butt waste, it is not necessary to have identified each and every toxic compound in cigarette butt leachate before we undertake to regulate and control it. The precautionary principle holds that when an activity raises threats to human health or the environment, precautionary measures should be taken even if some cause and effect relationships are not fully established scientifically, shifting the burden of proof to the proponent of the activity, ${ }^{21}$ and has been embodied in laws and in international treaties. $^{22}$

\section{A PRODUCT STEWARDSHIP APPROACH}

Product stewardship started in the USA ${ }^{2324}$ as an effort to shift the responsibility and the cost of protecting the environment from taxpayers to the manufacturer, retailer and consumer for products put in the stream of commerce: 'The greater the ability of a party to influence the life cycle impacts of a product, the greater the degree of that party's responsibility. The stakeholders typically include manufacturers, retailers, consumers and government officials'. ${ }^{23}$ This movement has gone global. ${ }^{25}$ Part of the process is to encourage manufacturers to make products that are not harmful to the environment, which in the case of cigarettes is not possible unless the tobacco and possibly the filter is removed from them, given the evidence accumulating on the hazardous content of discarded cigarette butts.

A related, but different, approach is the extended producer responsibility (EPR) concept, which places the onus of waste management for end-of-life products on the manufacturer, while product stewardship adds retailers and consumers into the process. EPR began to be implemented in Europe in the early 1990 s, and was incorporated into European Union environmental policy in 2002; to date it has not been considered at the federal level in the US. ${ }^{26}$

In the US, as of October 2010 a total of 32 states have enacted EPR laws that require manufacturers to finance the costs of recycling or safe disposal of their consumer products, covering a range of products including auto switches, batteries, carpet, cell phones, electronics, fluorescent lighting, mercury-containing thermostats, paint and pesticide containers. ${ }^{27}$ Most of this legislation is of recent origin, but it may be another model of regulations that could be adapted to cigarette butt waste.

EPR in Europe has not been perfectly implemented and may not be suited to the US. ${ }^{24} 26$ EPR laws enacted in US states have each dealt with a specific product, ${ }^{27}$ thus avoiding some of the issues found in Europe regarding a singular regulatory scheme being applied to a wide array of products with an overall goal of encouraging manufacturers to make design changes. The EU has not been as successful in meeting this goal on a large range of products, requiring direct design mandates such as materials standards and bans on use of certain chemicals. ${ }^{26}$ In the case of tobacco products, changing the product design to completely eliminate environmental hazards is not practicable. However, some have advocated the possibility of removing the filter from cigarettes in order to at least improve biodegradability of smoked cigarettes. ${ }^{1}$ This would not, however, eliminate hazardous leachates from butts containing only tobacco remnants.

In 2010, the State of Maine considered a bill to enact a comprehensive product stewardship law ${ }^{28}$ that would avoid the EPR problems experienced in Europe. Under the proposed law, the Maine Department of Environmental Protection would designate what products or product categories sold in Maine would be required to participate in a product stewardship program, financed and either managed or provided by producers of a designated product. No designated product could be sold or offered for sale in Maine by any producer, wholesaler, retailer, or other person unless the producer participated in a product stewardship program. The producer would pay all administrative and operational costs of the program, including the costs of collection, transportation and recycling or disposal, or both, of all products covered by the program. The proposed statute would prohibit charging the consumer a fee for taking or collecting the unwanted product, and require the producers to provide an education and outreach program to promote use of the program by consumers. The Department could also establish producer fees to fully recover its expenses in administering the law.

A producer or stewardship organization that operates a stewardship program on behalf of a producer or group of producers would have to submit a plan for approval by the Department of Environmental Protection that included a description of the collection, transportation, handling, processing, or disposal systems. In addition, the plan would have to explain how the collected waste would be reused or recycled or how it would be disposed of if the Department determined that the waste was not reusable or recyclable. The plan would also have to describe the education and outreach to be used, and it would have to provide information relating to consultation about the plan with stakeholders including consumers, environmental groups and retailers. Any subsequent revisions to the plan would have to be approved by the Department, and detailed annual reporting to the Department of plan operations would be required. Failure to submit a product stewardship plan, revisions, or annual report would have resulted in a fine of up to US $\$ 10000$ a day. Although not spelled out in the proposed statute, a producer, wholesaler, retailer, or other person selling or offering for sale a designated product for which the producer was not participating in a product stewardship program would be subject to an injunction to prohibit such sale or offer for sale.

The Maine legislature amended the original bill only to require the Department of Environmental Protection to propose a product stewardship law in 2011. Despite this delay, the proposed Maine product stewardship law offers a very good framework for laws applying to cigarette butt waste; however, existing state EPR laws are not as comprehensive as the product stewardship law proposed in Maine.

Because of the unique disposal issues surrounding cigarette butt waste disposal, any regulatory approach to such waste should include extensive consumer education about the environmental hazards of the tobacco product waste, and enhanced 
and better enforced penalties for improper disposal. The California litter law ${ }^{29}$ specifically designates cigarette butts as litter, imposes a fine of US\$250-1000 for their improper disposal and provides a reward of $50 \%$ of the fine to a person giving information leading to the arrest and conviction of a person littering cigarette butts or any other waste. The minimum fine can only be waived in unusual circumstances, and the court may also require the convicted person to pick up environmental litter for no less than $12 \mathrm{~h}$ as a further punitive measure.

In the absence of an EPR law or a product stewardship law such as that proposed in Maine, a more limited approach using several components of EPR or product stewardship could be adopted. Businesses could be required to place dedicated receptacles, as is often done with trash and recycling bins, for cigarette butts outside businesses where smokers congregate. Further, they could be required to collect all butts discarded on the ground rather than simply sweeping them into the street where they may then be washed into storm drains and subsequently into aquatic environments. All outdoor public areas should have adequate numbers of dedicated receptacles, or smoking should be prohibited in all outdoor public areas. To reduce the landfill burden of cigarette butt waste, households and businesses in which cigarette butt waste is generated could be required to collect all butts in special containers for collection by waste collection services so as not to mix toxic cigarette butt waste with other waste. Government waste collection agencies could be required to adopt measures to safely dispose of cigarette butt waste, including sending them back to the cigarette manufacturer for destruction or recycling, or to establish manufacturer fees to cover all of the mitigation costs created by every pack of cigarettes sold in the jurisdiction. A Maine-style product stewardship law would be far superior, as all of the costs would be borne by the cigarette manufacturer.

Many states and communities have passed laws and ordinances prohibiting smoking in parks and on beaches for public health and environmental reasons. Maine has prohibited smoking in all state parks and on state beaches; Puerto Rico along with a large number of US municipalities have prohibited smoking in parks, ${ }^{30}$ and many municipalities have prohibited smoking on beaches. ${ }^{31}$ In 2010, the New York City Council, supported by Mayor Bloomberg, proposed a total ban on smoking in all public parks, beaches and walkways. ${ }^{32}$ A law banning smoking in all state parks and beaches in California passed both legislative bodies, ${ }^{33}$ but was vetoed ${ }^{34}$ by thenGovernor Schwarzenegger as 'an improper intrusion of government into people's lives'. Notably, the Governor stated: 'As we have seen, marine debris and litter know no boundaries. I believe a more appropriate response is to increase the fines and penalties already in law for littering in our parks and on our beaches'.

There is likely to be further attention paid to cigarette butt waste as additional economic analyses are available regarding clean-up costs as well as indirect losses from environmental degradation, impacts on tourism and the public nuisance costs created by cigarette butt waste.

\section{THE PLUSES AND MINUSES OF THE OPTIONS}

The current single-product EPR laws in the US principal weakness is that they rely very heavily on consumers' voluntary compliance with proper disposal protocols, except where they exchange an end-of-life product with a retailer for a replacement product, such as automobile tyres and batteries, making effectiveness uncertain and largely unascertainable. Another weakness is that most such laws are essentially unenforceable with regard to consumer compliance. With EPR, the producer pays some or most of the cost of collecting and recycling end-of-life goods voluntarily delivered by the consumer to a collection point, usually provided by the local government. The local or state government is often responsible for consumer education, if any is undertaken.

In comparison, a Maine-style product stewardship law is very comprehensive and places all of the costs, administration and consumer education on the producer. In order to sell its product, the producer must file a plan to accomplish this and it must be approved by a governmental agency. The law would create a collaborative environment involving the producer, the government, consumers, environmental groups and other stakeholders. The environmental groups would fill a watchdog role. The challenge with this approach is in generating the political will of policymakers to adopt it.

In this Tobacco Control supplement, Smith and Novotny describe the tobacco industry's studies of smoker attitudes about cigarette butts, and those attitudes are substantial barriers to smoker voluntary compliance with any butt disposal protocol. Thus, vigorous enforcement of littering laws will likely be required early in the program until they change those attitudinal barriers.

Smith and Novotny also report on the efforts of the tobacco industry to modify smoker behaviour concerning cigarette butt disposal out of its fear of government regulation of butt disposal. The efforts failed, largely because the tobacco industry did not want to offend smokers. Traditional anti-littering campaigns have clearly not had much, if any, effect on smoker behaviour. Education of smokers about the environmental impact of their butt disposal habits may have some effect, along with the threat of littering fines. Because of the complex nature of smokers' behaviour regarding cigarette butts, further research on effective messaging is needed.

\section{SUMMARY AND CONCLUSIONS}

The best solution to the cigarette butt waste problem is for smokers to quit, whether for reasons of their own health, the health of others, or the health of the environment where more than 5 trillion cigarette butts are deposited each year. At a minimum, however, the economic and administrative burdens of cigarette butt waste should be taken off state and local government agencies and taxpayers, and, following the principles of product stewardship and extended product responsibility, tobacco manufacturers should shoulder the entire financial burden for the collection, transportation and safe disposal of cigarette butt waste. The next best solution is to adopt a comprehensive Maine-style product stewardship law covering cigarette butt waste.

Acknowledgements The author thanks Dr Thomas E Novotny, San Diego State University, San Diego, California, for his assistance in reviewing the manuscript.

Funding This work was funded by the University of California Tobacco-Related Disease Research Program IDEA grant no. 17T-0014

Competing interests None.

Contributors RLB was responsible for this work.

Provenance and peer review Not commissioned; externally peer reviewed.

\section{REFERENCES}

1. Novotny T, Lum K, Smith E, et al. Cigarette butts and the case for an environmental policy on hazardous cigarette waste. Int J Environ Res Public Health 2009;6:1691-705.

2. Litter Free Planet. Cigarette Butts: Exposing the Butts. http://www.litterfreeplanet. com/id6.html (accessed 30 Oct 2010). 
3. Keep America Beautiful. 2008 National visible Litter Survey and Litter Cost Research Study. http://www.kab.org/site/PageServer?pagename=focus_litter_ prevention (accessed 30 0ct 2010).

4. Micevska T, Warne M, Pablo F, et al. Variation in, and causes of, toxicity of cigarette butts to a cladoceran and microtox. Arch Environ Contam Toxicol 2006:50:205-12.

5. Huerta-Fontela M, Galceran M, Ventura F. Stimulatory drugs of abuse in surface waters and their removal in a conventional drinking water treatment plant. Environ Sci Technol 2008:42:6809-16.

6. Slaughter E, Gersberg R, Watanabe K, et al. Toxicity of cigarette buttes, and their chemical components, to the marine and freshwater fish. Tob Control 2011;20(Supp 1):i23-i27.

7. Hackendahl N, Sereda C. The dangers of nicotine ingestion in dogs. Vet Med 2004:218-24.

8. Schneider J, Decker C, Doyle A, et al. Estimates of the Costs of Tobacco Litter in San Francisco and Calculations of Maximum Permissible Per-Pack Fee. Morristown, $\mathrm{NJ}$ : Health Economics Consulting Group LLC, 2009. http://www.sfdpw.org/ftp/ uploadedfiles/sfdpw/director/annual_reports/tobacco_litter_study_hecg_062209[1] pdf.

9. City and County of San Francisco. Cigarette Litter Abatement Fee Ordinance, Ch. 105. (2009). http://library.municode.com/HTML/14131/level1/CH105CILIABFEOR. html.

10. Knight H. S.F's 20-Cent Cigarette Fee Headed to Court? San Francisco Chronicle (San Francisco, CA) 10 January 2010; Metro, C1. http://www.sfgate.com/cgi-bin/ article.cgi? $\mathrm{f}=/ \mathrm{c} / \mathrm{a} / 2010 / 01 / 10 / \mathrm{BA0l1BF5BT} . \mathrm{DTL}$.

11. Hager E. A Call to Recycle Cigarette Butts [Blog 25 May 2010]. New York, NY: The New York Times. http://cityroom.blogs.nytimes.com/2010/05/25/a-call-to-recyclecigarette-butts/ (accessed 16 Mar 2011).

12. Zhao J, Zhang N, Qu C, et al. Cigarette butts and their application in corrosion inhibition for N80 steel at $90^{\circ} \mathrm{C}$ in a hydrochloric acid solution. Ind Eng Chem Res 2010:49:3986-91.

13. Kadir A, Mohajerani A, Roddick F, et al. Density, strength, thermal conductivity and leachate characteristics of light-weight fired clay bricks incorporating cigarete butts. World Academy of Science, Engineering and Technology 2009;53:1035-40

14. U.S. Environmental Protection Agency. Combustion. http://www.epa.gov/ wastes/hazard/tsd/td/combustion.htm (accessed 27 Oct 2010).

15. U.S. Environmental Protection Agency. Scrap Tires. http://www.epa.gov/ wastes/conserve/materials/tires/index.htm (accessed 27 0ct 2010).

16. U.S. Environmental Protection Agency. Batteries. http://www.epa.gov/wastes/ conserve/materials/battery.htm\#batteryrecycle (accessed 27 0ct 2010).

17. U.S. Environmental Protection Agency. Household Hazardous Waste. http:// www.epa.gov/wastes/conserve/materials/hhw.htm (accessed 27 Oct 2010).
18. University of Missouri Extension Office of Waste Management. Household Hazardous Waste. http://extension.missouri.edu/owm/hhw.htm laccessed 27 Oct 2010)

19. Rodgman A, Perfetti T. The Chemical Components of Tobacco and Tobacco Smoke. Boca Raton, FL: CRC Press, 2008:933

20. Warne M, Patra R, Cole B, et al. Toxicity and a Hazard Assessment of Cigarette Butts to Aquatic Organisms [abstract, Interact]. 21-25 Jul 2002, Sydney, Australia: Interact 2002 - Programme and Abstract Book, 2002:1.

21. Kriebel D, Tickner J. Reenergizing public health through precaution. Am J Public Health 2001;91:1351-5.

22. Goldstein B. The precautionary principle also applies to public health actions. Am J Public Health 2001:91:1358-61.

23. Product Stewardship Institute. What is Product Stewardship? http://www. productstewardship.us/displaycommon.cfm?an $=1$ \&subarticlenbr $=55$ (accessed 28 Oct 2010).

24. Short M. Taking back the trash: comparing european extended producer responsibility and take-back liability to U.S. environmental policy and attitudes. Vand J Transnat'l L 2004;37:1217-54.

25. Global Product Stewardship Council. http://productstewardshipcouncil.net/ (accessed 28 Oct 2010).

26. Sachs N. Planning the funeral at the birth: extended producer responsibility in the European Union and the United States. Harvard Environ Law Rev 2006:30:51-98.

27. Product Stewardship Institute. Extended Product Responsibility State Laws as of October 2010. http://www.productstewardship.us/displaycommon.cfm? an $=1$ \&subarticlenbr $=280$ (accessed 28 0ct 2010)

28. LD 1631, An Act to Provide Leadership Regarding the Responsible Recycling, Maine House of Representatives, 124th Sess. 2009. http://www.mainelegislature.org/legis/ bills/display ps.asp?ld=1631\&PID=1456\&snum=124 (accessed 28 0ct 2010)

29. California Penal Code $\S 374$ et Seq. (2010).

30. Americans for Nonsmokers' Rights Foundation. Municipalities with Smokefree Parks Laws. http://www.no-smoke.org/pdf/SmokefreeParks.pdf laccessed 30 Oct 2010)

31. Americans for Nonsmokers' Rights Foundation. Municipalities with Smokefree Beaches Laws. http://www.no-smoke.org/pdf/SmokefreeBeaches.pdf laccessed 30 Oct 2010).

32. Rosenberg N. Heated Debate at Hearing on Smoking Ban in Parks [Blog 14 Octobe 2010]. New York, NY: The New York Times. http://cityroom.blogs.nytimes.com/ 2010/10/14/air-cleared-at-parks-smoking-ban-hearing/?scp=2\&sq=smoking\%20ban \%20in\%20parks\&st=cse (accessed 16 Mar 2011).

33. SB 4, California Legislature, 2009-10 Sess. 2010. http://www.leginfo.ca.gov/pub/ 09-10/bill/sen/sb 0001-0050/sb 4 bill 20100416 enrolled.pdf.

34. Schwarzenegger A. Veto Message, SB 4. 2010. http://www.leginfo.ca.gov/pub/ 09-10/bill/sen/sb_0001-0050/sb_4_vt_20100503.html (accessed 16 Mar 2011). 